\title{
Being Explicit about Culture: Māori, Neoliberalism, and the New Zealand Parliament
}

\begin{abstract}
In this article, I explore how people use the culture concept in legislatures to understand the minorities they legislate for and about. I focus on recent debates in the New Zealand parliament over whether the indigenous Māori are a cultural group or a racial group. A Westminster parliament system encourages these debates, in which political parties argue that Māori are either cultural or racial but not both. For the ruling Labour Party and its allies, Māori are cultural; for their opposition, the National Party and its allies, Māori are a racial group. This division is possible only because of the legislators' neoliberal assumptions about identity categories. To complicate these political divisions, Māori MPs currently belong to political parties from all parts of the political spectrum, and their effectiveness as culture bearers in a parliamentary context can disrupt the terms of this debate. [Keywords: democratic representation, indigeneity, culture concept, legislatures, New Zealand]
\end{abstract}

$\mathbf{W}$ HEN ANTHROPOLOGISTS turn their ethnographic attention to how the culture concept travels, they find that institutional contexts configure what counts as cultural and what counts as acultural. In doing so, these institutions also determine the consequences of classifying with the culture concept, both for the people who apply the concept and for those to whom it gets applied (Briggs 2001; Dusenbery 1997; Handler 1988; Santiago-Irizarry 1996; Taylor 2003). For example, Vilma Santiago-Irizarry recounts how culture becomes "an array of psychologized symptoms" (Santiago-Irizarry 1996:3) when psychiatrists use culture as a lens for understanding mental illnesses among their patients, affecting how the psychiatrists treat those patients they interpret as culture bearers (Santiago-Irizarry 1996). Similarly, Bonnie Urciuoli finds that administrators in liberal arts colleges understand experience with culture, and more specifically with cultural diversity, to be part of a skill set that these colleges can now provide students (in press). In this article, I turn to legislatures and explore how members of the New Zealand/Aotearoa parliament deploy culture and race as opposing classificatory categories when debating policies affecting the indigenous Māori.

The act of legislating often raises a difficult question: How should one classify a group so as to make it into an appropriate legislative object? People enlist culture, along with race, ethnicity, and similar identity categories, when framing their constituents as members of groups requiring legislative action. Each category contains its own legislative possibilities and constraints. I use a limited form of discourse analysis to analyze the competing classifications political parties use to discuss legislation and policies viewed as addressing Māori concerns (see Chock 1991, 1996 for parallel analyses of classificatory categories used in the U.S. Congress). The parliamentary debates surrounding Māori as cultural are heavily influenced by the neoliberal assumption that culture is a useful skill set that can assist people in their market relations, an idea voiced by some members of all political parties with the exception of the Māori Party. I discuss how these debates are neoliberal and then address how the presence of Māori members of parliament (MPs) complicates these debates.

From 2003 to 2006, the New Zealand parliament explored the hazards of making culture an explicit basis for legislation in debates between the ruling Labour Party and its allies and the opposing National Party and its allies. ${ }^{1}$ New Zealand ethnographers have discussed the ways culture has been essentialized for different New Zealand publics (Fleras and Spoonley 2000; Goldsmith 2003; Murray 2000; Sissons 1993; Webster 1998). Michael Goldsmith has pointed out the costs of adopting "culturespeak" in New Zealand institutions (Goldsmith 2003). In parliament, the recent ways people essentialize culture has changed how culture and race as terms are interwoven. Often when culture is a term linking people and their practices, it is used in mutually constitutive relationships with other terms such 
as race or class (Segal 1998; Urciuoli 1996; Wetherell and Potter 1992). Typically it is impossible to make reference to race without implicitly also making reference to culture (Wade 1993). What is intriguing about the 2003-06 debates in the New Zealand parliament is that the two major political parties no longer exhibited this tendency to imply culture when speaking about race, or vice versa. The Labour Party, traditionally liberal, insisted on viewing Māori as cultural, a definition also referring to Māori's historical centrality in founding New Zealand/Aotearoa as a nation. In particular, the Labour Party and its allies described Māori as a cultural group with special status as the indigenous partner to the Crown under the Treaty of Waitangi, a document signed in 1840 in which Māori granted the Queen (contested) authority in exchange for various protections over land, fisheries, and taonga (lit., treasures). ${ }^{2}$ The National Party, traditionally conservative, shifted in its understanding of how to engage with New Zealand/Aotearoa's origins legislatively, the better to oppose Labour. They asserted that culture has no place in construing a legislative object and advocated that legislation should be without reference to race or culture. In this sense, culture and race mutually constitute each other in New Zealand parliamentary debates as opposing concepts with political consequences.

The paradoxes of democratic representation ensure that the current division between culture and race is unstable. Legislators attribute Māoriness to Māori discussed in Parliament in different ways than they attribute Māoriness to Māori who speak in Parliament. The Māori discussed might be either cultural or racial, depending on one's political affiliations. But Māori who speak will only accept being culture bearers, speaking for an otherness that carries with it political obligation. This is one of the few political stances that Māori from all political parties seem to agree on. Māori MPs rarely speak with a unified voice, as there is little agreement about what is in Māori's best interests. But all Māori MPs seem to agree that Māori MPs are representing a cultural group when they speak for Māori and that they, as representatives, share with their Māori constituents a nuanced and distinct perspective. The presence of the newly formed Māori Party has only serves to cement this stance, as I discuss later. Having Māori speaking in Parliament, insisting that their parliamentary consociates acknowledge and legislate based on Māori MPs' own understanding of what it means to be Māori, changes how the politics of recognition plays out in the New Zealand parliament. New Zealand legislators who are not Māori must take into account the unusually unified response by Māori MPs-their political allies-to the question of how to define Māori as an appropriate legislative object.

This has broader implications for indigenous people worldwide, because New Zealand's history offers rare insight into the benefits and costs of indigenous selfrepresentation in a national legislature. Indigenous selfrepresentation affects not only how Māori interests are represented but also how Māori are understood legislatively to be constituted as social groups. The New Zealand parliament is a historically rich site for examining how people use the culture concept in democratic representation as well as for analyzing the conundrums of classification that often accompany political representation. New Zealand/Aotearoa has the longest history of indigenous selfrepresentation in a national legislature. In 1867, four seats were reserved in the House of Representatives for Māori to represent themselves, a number that increased when the government switched to mixed member proportional representation in 1996. The recent 2005 election gave 21 seats to Māori out of 120 total seats, with the Māori Party in control of four of these seats. In addition, since 1975, Māori politicians have also been regularly elected to general seats that are not decided by votes from the Māori electoral roll (Wanna 2005). Māori presence in parliament has been influential over the past 140 years in shaping legislation that supports one of the more successful indigenous rights movements. Māori MPs intervene significantly, influencing parliamentary debates about Māori as a population, an object of public policy, and a group with unique claims on the government. Most recently, Māori MPs have had to figure out how best to advocate for their Māori constituents when faced with various neoliberal definitions of culture.

I have divided this article into three parts. First, I discuss literature on indigenous self-representation. Second, I focus on how culture is mobilized to describe Māori as a legislative object in a neoliberal context. Finally, I move beyond the discussion of the political debates surrounding whether Māori are a culture or a race, asking what happens when Māori figure not simply as a population under discussion but also as political consociates with whom one debates and compromises.

\section{THE CONSTRUCTION OF REPRESENTATION}

What do anthropologists bring to questions surrounding democratic representation $?^{3}$ One helpful intervention has been to point out that the categories themselves-gender, race, and culture-are not givens but, rather, are constantly constructed in the moment of their performance in legislatures (see Chock 1991, 1996). To ask how minorities represent themselves is also to ask how that particular identity category is constructed and what ideas of representation are presumed. The burgeoning anthropological literature on indigenous self-representation, largely based in Latin America, explores relationships between cultural and political representation. These scholars tend to address political representation outside of legislatures, focusing on indigenous activism and political strategies that various Latin American indigenous peoples have developed to navigate their nations' politics of recognition (Conklin 1997; Warren and Jackson 2002). ${ }^{4}$ They turn ethnographically to people's "political self-consciousness" (Warren and Jackson 2002), 
asking when and how indigeneity becomes a basis for social movements and critiques and observing how indigenous advocates invoke the culture concept to legitimate their claims on the state. Kay Warren and Jean Jackson discuss this idea, countering possible critiques by suggesting that "for anthropologists, the issue is not proving or disproving a particular essentialized view of culture but rather examining the way essences are constructed in practice and disputed in political rhetoric" (2002:9). In examining how and when indigenous people choose to essentialize their culture for political reasons, these scholars also explore what parts of their culture are turned into a political resource (Conklin 1997; Jackson 1991, 1995; Ramos 1998). Many studies explore transformations between how people perform their political acumen and cultural expertise within their indigenous communities and how they perform for NGO or state officials (Conklin and Graham 1995; Oakdale 2004; Warren and Jackson 2002).

Anthropologists studying indigenous self-representation insist that the medium employed shapes how these representations circulate and create their effects (Conklin 1997; Graham 2002). In analyzing Brazilian Amazonian self-representations, Laura Graham calls attention to the distinctive ways language and language ideologies influence representations (Graham 2002). Graham focuses on how Brazilian language ideologies present savvy indigenous spokespeople with potential pitfalls when they are faced with the challenges of fashioning an indigenous persona that performs authenticity in ways that are recognizable to the nonindigenous Brazilian gaze. Current Māori MPs rarely encounter a comparable struggle to produce a putatively authentic Māori presence: this is a battle that took place more frequently 20 or 30 years ago. ${ }^{5}$ Yet Graham's intervention does not hinge on questions of authenticity alone. She recommends that ethnographers examine the tension between people's ideas about language and their actual speaking practices when studying indigenous political representation. This is particularly appropriate for parliaments, because almost all parliamentary labor centers on producing texts-that is, laws as well as parliamentary transcripts.

For example, in the New Zealand parliament, Māori MPs will speak in Māori, addressing the other MPs who are present and, implicitly, those constituents listening. ${ }^{6} \mathrm{Te}$ Uroroa Flavell (Māori Party) addressed the Speaker of the House (who is not Māori) in the following manner:

\footnotetext{
I te tuatahi, e pātai noa ake ana ki a koe Madam Speaker kia waiho tēnei pātai mō āpōpō i te mea, kāore te Minita i konei.
}

I seek leave, Madam Speaker, to have this question left for tomorrow because the Minister is not present. [New Zealand, Parliamentary Debates, May 23, 2006, Te Uroroa Flavell, MP]

This sentence does not contain Māori-inflected concepts. Flavell is performing standard parliamentary business that could be done as effectively in English as it could in Māori. Graham suggests that to understand such indigenous self-representation, one should pay attention to how language as a medium functions as a second-order indexicality, a concept introduced by Michael Silverstein (1998, 2003). She defines second-order indexicality as "the processes by which signs take on novel indexical meanings in new contexts that were only latent in earlier ones" (Graham 2002:190), arguing that speaking an indigenous language signifies far more than the semantic content of the utterance. The indigenous language itself references the chain of associations linked to that local manifestation of indigeneity: "Māoriness" or "Indianness," for example. In the example above, speaking Māori accomplishes two tasks, made possible because the Māori language is largely interpreted as a second-order index in parliament: first, Flavell reminds his audience of Māori's status as an equal partner in fashioning New Zealand/Aotearoa as a nation, especially because Māori and English are New Zealand's official languages; second, he asks implicitly that the MPs (and the parliament's larger audience) who do not understand Māori engage with the systemic exclusions that Māori experience in non-Māori contexts. He refuses to be one of the few compelled to be culturally out of place in parliament. ${ }^{7}$ In other instances, Māori members are also using Māori to insist on the untranslatibility of Māori concepts and, in doing so, to emphasize the distinctiveness of a Māori perspective.

Expanding on Graham's insight, all representations of Māori in parliament are ones in which the message's second-order indexicality predominates, especially because politicians do not generally understand parliament to be a Māori context. Speaking in parliament as a Māori or about being Māori always provides emblems of Māoriness with novel (legislative) meanings that perhaps were implicit in the sign's other contexts. For example, in other Māori political contexts, how a speaker is connected to others genealogically or through iwi or hapū (often translated as tribes or subtribes) is crucial. In parliament, Māori speakers rarely mention their iwi or hapū affiliation. ${ }^{8}$ They tend to speak as representatives of Māoridom, rather than as representatives of Māori-specific social unities. When Māori iwi or hapū are discussed in parliament, it is almost always as legal objects to be addressed under the Treaty of Waitangi. As ethnographers of Latin American indigenous representation have noted, internal divisions often fall away when indigeneity or Indianness is treated as second-order indexicality (Warren and Jackson 2002). Parliament as a context provides a similar kind of filter, ensuring the dominant focus is on Māoridom as a whole. In short, second-order indexicality is the order of the day when Māoriness is a legislative object or a public marker of a legislator's identity.

I am distinguishing parliament as an institution from government institutions in general, and the courts in particular. Scholars have noted that court officials characterize indigenous people as cultural in substantively different ways than I have found that legislators do. For example, 
in the New Zealand parliament, Māori, whether framed as cultural or as racial, are not necessarily defined by their precolonial practices, which Elizabeth Povinelli argues is the case in courts. Povinelli claims that the liberal nation-state views indigenous people seeking redress as unfortunately corrupted representatives of the precontact cultural other (Povinelli 2002). Indigenous people are presumed to have knowledge of what traditional laws and other practices used to be prior to colonialism or modernity. They do not live according to these principles currently, because they are forced to navigate modern systems, such as the capitalist market. According to Povinelli, this failure to be properly culturally other undermines indigenous claims for redress. ${ }^{9}$ This is not how being indigenous is discussed in the New Zealand parliament, a nation with its unique history of indigenous relations. For the most part, New Zealand parliamentarians describe Māori culture as a distinct changing culture. Pakekura Horomia, the Māori Labour Minister of Māori Affairs, argues that "custom and ritual are still strong for us, but culture is not static, and Māori must not hold themselves back by not being prepared for modern times and not getting modern skills" (New Zealand, Parliamentary Debates, February 2, 2005). Although not always stated so explicitly, generally in parliament culture is taken to be a worldview motivating a set of practices that people use to organize their contemporary lives. ${ }^{10}$

\section{MĀORI AS NEOLIBERAL RACE, MĀORI AS NEOLIBERAL CULTURE}

In this article I focus on the consequences of invoking culture when debating indigeneity in parliament. Yet discussing indigeneity is not in fact when people most frequently use the term culture in the New Zealand parliament. Members of all parties most often invoke a corporate notion of "culture" when previously terms such as environment or atmosphere might have been used. ${ }^{11}$ MPs of all political persuasions talk about "the culture of extravagance," the "culture of saving," or the "culture of dishonesty." 12 In these moments, the speakers open up the possibility of change by describing an environment of dishonesty as a culture of dishonesty. Culture divorced from communities points to a different kind of legislative possibility than Māori culture does, largely because these types of cultures are not perspectives whereas people's cultures are. The "culture of" discourse points to practices without perspectives. To speak of the "culture of" something opens up possibilities for conscious and systematic transformations of the culture in ways that people's cultures (understood as tacitly held beliefs) cannot be changed. The speakers often suggest how to transform the culture, whether through legislation, new leadership, or conscious decisions. In addition, when speaking about "culture of," speakers are not merging people and culture into a single legislative object. Instead, speakers distinguish between people and their practices, making only their loosely defined practices available for legislative attention.
When National MPs hear the term culture in relation to Māori, they view it as a codeword for race, ${ }^{13}$ as Tony Ryall (National Party) implies when debating a tax bill exempting Māori cultural organizations:

The bill has the quite innocent-sounding phrase "Māori Organisations" in its title. ... What it does have a lot to do with is the provision of preferential tax treatment on the basis of the colour of one's skin, and that fact is not reflected in the title. This bill has nothing to do with setting up or establishing Māori organisations, and everything to do with providing a tax break based solely on the colour of someone's skin. It is bad that that could be allowed to happen. ... The words "Race-based Tax Rates" should be in the title because that is what is in this bill. [New Zealand, Parliamentary Debates, March 6, 2003, Tony Ryall, MP]

Ryall was one of many National MPs and National allies who described legislation addressing Māori concerns as race-based legislation or race-based laws. ${ }^{14}$ Other allies of National, and in particular ACT New Zealand party members, argued consistently against race-based laws or legislations as well. ${ }^{15}$ For example, ACT MP Heather Roy, in a general and sweeping critique of recent legislation, also moves quickly from cultural assessment to race-based law:

I ask all parties to think about legislation of all sorts that has been brought before the House of late. Cultural assessment of all sorts has become a trend with this Government. It is becoming a very big part of its bills, and also we are seeing the specific singling out of Māori. We should in this country have one law for all people, not race-based law. What we are seeing here is, again, a perpetuation of the push towards the promotion, the singling out, of separate ethnic groups within our society. What that does in effect is cause separatism, not a united New Zealand. [New Zealand, Parliamentary Debates, October 23, 2003, Heather Roy, MP]

By insisting that what Labour and its allies call "culture" is in fact race, National MPs and their allies can advocate for changes in policies that they believe privilege one race over another: for example, eliminating the seven parliamentary seats currently designated only for Māori. Historically culture and culture loss has been the category Māori used to demand restitutions from the state. Defining Māori as racial is a way to sidestep obligations arising from historical injustices. National MPs instead frame Māori problems in terms of contemporary economic inequalities. Through these techniques, the National Party tries to eliminate Māori as a population requiring special legislation.

To examine the National Party's perspective in detail, I turn to former National leader Don Brash's speech to the Orewa Rotary Club on January 27, 2004. ${ }^{16}$ This was the first speech in which Brash delineated for the New Zealand public why he views Māori as a race first and foremost and views culture as a group's secondary-and legislatively inconsequential—characteristic. This speech also answers the question "why now?" Why would National legislators distinguish between culture and race now, in this particular 
political climate? Brash's speech reveals that this political strategy extends a neoliberal logic; it emerges from a New Zealand neoliberal take on what it means to have a culture. ${ }^{17}$ And who better to delineate the New Zealand neoliberal perspective on identity categories than the former governor of the Reserve Bank of New Zealand?

In his Orewa speech, Brash outlines his principles for refusing to accept that Māori can be an object of legislation because of their culture. He acknowledges that Māori have a culture as well as are a race but argues that having a culture does not lead to a group identity that legislation should address. Thus, any legislation that addresses being Māori is legislation built on "preferences based on race" (New Zealand, Parliamentary Debates, December 16, 2003, Don Brash MP). Generally Brash claims that culture is not legitimate as a basis for a group because it is a skill set, something that people can consciously use in the marketplace. Brash and other neoliberals view the self as a bundle of usable traits that can be selectively employed to forge profitable alliances. This has implications for how National members understand their constituents' needs. They don't use culture to place an individual within a context (however that context is defined); instead, they try to identify the traits that individuals possess the better to lump together people who share similar traits. ${ }^{18}$ Brash describes culture explicitly as a trait that assists one in the market at two moments in his speech. First, he suggests that Māoriness entails a flexibility that can serve one in good stead in rapidly changing contexts:

in spite of all the turmoil, the shocks from the collision of two cultures and the chaos of unprecedented social change, the documentary evidence clearly shows that Māori society was immensely adaptable, and very open to new ways. That adaptability and resourcefulness, that openness to opportunity, that entrepreneurial spirit, is something that survived the trauma of colonisation, and is today reflected in a Māori renaissance across a wide range of business, cultural and sporting activity. [Brash, Orewa Rotary Club speech, January 27, 2004]

It is no accident that Brash equates adaptability and resourcefulness with having an entrepreneurial spirit. For Brash, Māoriness is but one path to the entrepreneurial spirit, one of many possible approaches toward learning techniques for entering into market relationships. It allows people to enter into alliances with others, potentially offering the skill set of Māoriness as a complement to people with other skill sets.

Second, Brash argues that one can choose to develop this particular skill set over other skill sets. He is not opposed to teaching people how to be Māori if they are biologically capable-that is, racially Māori. And in making this argument, he stresses in the following passage the fact that this is a choice, similar to any other choice structured by market rationality:

Similarly, a National Government will continue to fund Te Kohanga Reo, Kaupapa Māori, Wananga and Māori primary health providers-not because we have been conned into believing that that is somehow a special right enjoyed by Māori under the Treaty, but, rather, because National believes that all New Zealanders have a right to choice in education and health. [Brash, Orewa Rotary Club speech, January 27, 2004]

Here, he rejects the idea that being Māori entails historical claims on the nation, insisting instead that being Māori is a bundle of skills that one can choose to develop, if biologically Māori. Brash accepts here the premise that the government might be responsible for ensuring that any citizen is properly educated for the marketplace. Because Māoriness is a variant of entrepreneurial spirit, this entails offering educational opportunities to learn how to be Māori.

For Brash, Māori culture is one skill set among many, and thus it can not serve as the basis for political distinctiveness. Brash argues for a specifically New Zealand neoliberal perspective, one that contrasts with how neoliberals address indigenous claims elsewhere. Several scholars have pointed out that culture does not pose the challenges to neoliberal capitalism that culture has posed in the past to other forms of capitalism (see Comaroff and Comaroff 2007; Coombe 2005; Hale 2006). Jean Comaroff and John Comaroff as well as Charles Hale argue that indigenous groups can now use their cultural identity as grounds for becoming corporate entities and that a limited cultural unity is acceptable to neoliberal organizations when framed as the source of a corporate mandate. Outside of New Zealand, neoliberals can tolerate culture as long as those claiming culture form a social unity that for all intents and purposes is a corporate entity.

Brash-as well as the National Party as a wholeis unwilling to grant Māori such status, largely because this would reconfigure the Treaty partnership between the British Crown and Māori into a partnership between two corporate entites. The Treaty of Waitangi, understood as the originary document of the New Zealand nation, is considered a legal contract structuring New Zealand/Aotearoa as a nation and a partnership in which Māori and the Crown are equal Treaty partners. For the National Party, all partnerships are inherently alliances based on market principles, and thus the Treaty allows Māori to claim a unique business standing. Brash spends most of his Orewa speech arguing against this possibility, insisting that Māori should not occupy a unique position in relationship to the nation. He is particularly concerned that they will be (wrongly) privileged when entering into business alliances. This trepidation is apparent in the following passage:

Māori also gain a new role in the management of the entire coastline. Customary title will give commercial development rights, which over time will inevitably erode public access. In addition, 16 newly created bureaucracies will give Māori a more dominant role than other New Zealanders in the use and development of the coastline ... Māori will gain access to even more taxpayers' funds for consultants, lawyers and hui [Māori public meetings] 
to "build capacity" to take part in this process. [Brash, Orewa Rotary Club speech, January 27, 2004]

Brash is concerned that the Treaty frames Māori as fundamentally different kinds of citizens and, hence, inappropriately advantaged businesspeople. From a neoliberal perspective, governments' primary function is to maintain environments conducive to marketplaces. Defining Māori as special because of their indigeneity undercuts the government's ideological responsibility to create equitable market conditions.

Brash hopes to create "one standard of citizenship for all" by viewing Māori as first and foremost a race and seeing culture is a secondary skill set relevant only for entering marketplaces. "One standard of citizenship for all" refers to equitable market alliances: that is, Brash does not want some to be disproportionately advantaged because of their historical relationship to the nation's origins. Brash chooses to privilege race over culture to make historical connections less salient. Race becomes an acultural category for Brash precisely because it is not a skill set. Race is, in his evident understanding, a biological trait that has (in an ideal neoliberal world) no impact on how one engages with the market. Even race is a category he is reluctant to use to suggest that Māori are a distinct group, because he understands all Māori to be too racially mixed. In this speech, and subsequently, Brash keeps referring to his impression that there are no "pure" Māori left: everyone currently claiming to be Māori is the result of many intermarriages. ${ }^{19}$ For Brash, claiming that Māori are a race, however putatively impure, allows him to extend National's neoliberal logic to argue against Māori as a legislatively distinct population. Now that Brash is no longer the head of the National Party, no MP is publicly claiming that Māori are a vanishing race. Yet National Party members still argue that any legislation or representation geared toward Māori is race based and, hence, illegitimate.

Labour, by contrast, insists that the Māori population remain a central object of legislation. In doing so, Labour is not rejecting a neoliberal perspective on culture. Labour and National politicians agree, in fact, that culture can offer an important skill set. Both agree that culture can be New Zealand's solution to the problem of meeting globalization's demands for specialized skills. Chris Carter, Labour Minister for Ethnic Affairs, suggests an argument for diversity based on the marketplace:

The diversity of the world is now a global market, and if young people in New Zealand are aware of cultural difference, and appreciate and celebrate other cultures, they are enriched and stronger in embracing those cultures. They should inevitably do that because of the way barriers are breaking down in the world. [New Zealand, Parliamentary Debates, February 11, 2003]

For Carter, and other Labour politicians, managing cultural difference is a skill set that the government can help foster. Where the Labour Party and National Party split is that Labour insists on seeing culture as also a perspec- tive, not just a skill set alone. Labour politicians claim that a nation's culturally diverse population is comprised of groups holding different and equally valid perspectives. They may share common goals. For example, every family wants to raise healthy and flourishing children, although the paths toward these shared goals are culturally distinct. ${ }^{20}$ The dilemma thus is writing laws to promote common goals while allowing people to reach these goals via their different cultural paths. Prime Minister Helen Clark, in rebutting Don Brash's Orewa speech, outlines this stance:

I think the challenge for us in New Zealand is to keep building in our small country the tolerance and mutual respect for each other that allow diverse peoples to live alongside each other in peace. Trying to enforce a monoculture that does not allow for diversity of culture, heritage, and belief would be a disaster for this country. [New Zealand, Parliamentary Debates, November 15, 2005, Helen Clark PM]

The Labour Party is continuing legislative efforts begun in 1975 when parliament founded the Waitangi Tribunal to adjudicate Māori claims of unfair land dealings. Labour claims to be committed to historical redress and has required that all relevant legislation speak to Treaty principles. But the party is doing more than insisting that Māori should have legislative status as Treaty partners. Labour politicians assert that a Māori perspective is fundamentally different than a European New Zealander perspective. Government coalition MPs will call on a Māori cultural logic in their speeches. For example, Judy Turner (United Future) says: "One of the aspects of tikanga [customs] Māori that I most admire ... is the concept that we move forward into the future by backing into the future. My understanding is that the thought is that we make decisions about our future from that which we can learn from what has gone before, and I admire that" (New Zealand, Parliamentary Debates, March 26, 2003, Judy Turner MP). Judy Turner argues that Māori have uniquely cultural relationships to history, metaphorically spatialized as moving forward by looking back to the past. When Labour defines Māori as cultural, then, the party claims that Māori have a worldview, framed in a way that resonates with a much-critiqued anthropological concept of "cultural logic" (for anthropological critiques, see Abu-Lughod 1991; Strathern 1995; Wagner 1981).

This raises a new question: How does this concept of cultural logic, so similar to an anthropological one, affect parliamentary decisions when legislators use the concept to imagine the needs of the minorities that they legislate for and about? ${ }^{21}$ Mostly Labour politicians argue for bureaucracies that allow people to have a range of different cultural approaches. ${ }^{22}$ Like many other neoliberals, they insist on viewing government officials and the people they interact with as allies in transactions structured according to market principles. People requesting state housing or welfare benefits are "clients" with their own skill sets, including culture. At the same time, bureaucrats also have their own skill sets 
that allow them to make certain alliances with the clients. The task legislators are faced with is devising policies that encourage these alliances rather than hinder them. This becomes clear in the following interchange between Steve Maharey (Labour Minister of Housing), and Rodney Hide (Leader of ACT and allied with the National Party):

RODNEY HIDE (Leader-ACT) to Steve Maharey (Minister of Housing): Does Housing New Zealand Corporation have a "two-world view" of the Treaty of Waitangi; if so, what two views of the world does Housing New Zealand Corporation have? ${ }^{23}$

Hon. STEVE MAHAREY (Minister of Housing): No, the corporation does not have a "two-world view" of the Treaty of Waitangi. The corporation simply acknowledges that different people have different ways of looking at the world, often based on their distinct culture, traditions, and beliefs. [New Zealand Parliamentary Debates, October 7, 2004, Rodney Hide MP and Steve Maharey $\mathrm{MP}]$

Throughout the much longer discussion, Steve Maharey insisted on seeing cultural difference in terms of points of view that might shape the ways that clients should be treated. Here culture is a potential obstacle for creating effective alliances as well as a potential basis for the alliances. Culture becomes a legislative object precisely because the Labour party sees law and government policies as vehicles for promoting alliances that have culture as a core element.

Each political side understands culture through a neoliberal lens. Culture for each party serves as a useful skill set, one that helps people navigate complicated marketbased relationships. This motivates both parties to support some government initiatives, such as language preschools. The difference is that the National Party sees culture as one of many usable traits that a person possesses, whereas the Labour Party sees culture as a usable perspective. For the National Party, usable traits should not be the grounds for legislation: for example, why legislate based on whether some people can speak a language in addition to English whereas other English speakers cannot? Usable perspectives, unlike usable traits, are a double-edged sword necessitating legislative attention, because perspectives serve as the basis for certain alliances but also undermine other interactions. Labour insists that it is possible to create bureaucracies that support multiple perspectives; indeed, the presence of multiple perspectives requires equitable government support. Cultural perspectives provide challenges to government bureaucracies that can be responded to legislatively. These contrasting neoliberal conceptions of culture entail two distinct legislative implications. The tension between these implications has led to the current debate about whether Māori should be objects of legislation or not.

\section{MĀORI AS MEMBERS OF PARLIAMENT}

A history of over 140 years of indigenous self-representation in the New Zealand parliament means that the question of how to characterize Māori cannot be distinguished from the question of how to represent them politically. For example, if Māori are characterized as a race, then the Māori seats are reserved for people who represent others based on racial commonalities. If Māori are characterized as a culture, then the Māori seats are filled by people who represent those who share their cultural perspective. Yet justifying democratic representation ensures that the question of how a representative is linked to constituents crops up outside the context of debates about whether indigenous seats should exist or not. The Māori presence in parliament affects any debate about how to conceptualize either Māori or New Zealand as a nation.

In asking about how the presence of Māori MPs shape debates about national identity, I build on Phyllis Pease Chock's (1991) suggestion that a nation's origin stories can pose central dilemmas to people when they distinguish between legislative object and legislator. She examines the 1975 U.S. Congressional subcommittee hearings on immigration to see how the U.S. myth of opportunity informs debates about illegal migrants. The presence of people willing to discuss their own families' historical trajectories to the United States altered the tone of the debate, undermining others' attempts to address migrants only as legislative objects (Chock 1991:281, 290). Reflecting on their historical connections to this dilemma, the representatives and expert witnesses made visible their own historically nuanced relationship with the nation. In so doing, the U.S. representatives made their personal histories a basis for connecting with those they legislate. In short, representatives often can reflect on their own cultural or historical connections as a rhetorical resource when arguing for particular laws.

Just as in Chock's study, when Māori MPs bring their personal background into the debate, they often do so to disrupt how those they represent are construed as legislative objects. ${ }^{24}$ Almost none of the Māori MPs use the "culture of" construction. Instead, when they speak about what it means to be Māori, they tend to emphasize differences of both social organization and epistemologies. These differences are referred to, not explained or elaborated, in accord with the tendency toward using second-order indexicalities mentioned earlier. For example, Metiria Turei (Green Party) argues for a change in tax law in the following way:

We are pleased that the definition of "charitable purpose" has been extended to include those who are related by blood. Traditional Māori structures that prioritise whānau [family] and hapu [tribe] have had real difficulty in gaining recognition as valid structures in our society. Once defined as "beastly communism," those structures are actually fundamental to Māori cultural, economic, and political development. The extension of the charitable purposes definition goes some way towards ensuring that Māori authorities and marae [meeting place] are no longer prejudiced by inappropriate, culturally biased definitions. [New Zealand, Parliamentary Debates, March 19, 2003, Metiria Turei MP; emphasis and definitions added] 
In this speech, Turei reminds her audience that both Māori and current European New Zealand structures have historical trajectories, before emphasizing the justice of recognizing and supporting Māori social structures. She and other Māori MPs argue that the government should respect the complexities of Māori culture and often refute other legislators' reductionist gestures toward Māori culture.

Even as Māori MPs speak for and about what it means to be Māori, they are also constantly being told by other European and Māori MPs how they should stand for Māoriness. In part, this reflects how people use language in parliament. Parliament is an arena in which people understand that they are using language both to comment on the nation and try to shape it. As a result, parliament is also an arena of a particular form of explicitness: it is a laboratory for metapragmatics in which people are constantly experimenting with using reflexive language to move others to legislate in the desired manner. In other words, people in parliament are constantly telling each other what the world should be like, how others should speak, and what others should be. ${ }^{25}$

Intriguingly, given how much instruction is constantly occurring in Parliament, Māoriness is currently the only identity category that inspires instruction. MPs are constantly invoking Māoriness and telling the Māori MPs on the other side of the political divide that they should be true to Māori interests instead of party interests. A close analysis of parliamentary transcripts reveals that in one recent year alone (2003), Māori MPs were informed 93 times what it should mean for them to be Māori. For example, Gerry Brownlee (National Party), in arguing against allowing MPs to have dual citizenship, suggests how Māori MPs should vote: "I want to ask the Māori members, particularly, how comfortable they are with the idea that foreigners can sit in this Parliament and determine their destiny-because that is what they are voting for" (New Zealand, Parliamentary Debates, August 7, 2003, Gerry Brownlee MP). Recommending that Māori members of another political party act differently is a common political strategy. Yet no MP suggests that women or those of Asian descent in another political party should legislate differently than other members of their political party. Māoriness is the only category that seems to encourage this form of consociate education.

In short, the category of "Māori" is treated as politically distinct in parliamentary contexts, as Māori MPs constantly get told that behaving properly means going against their party and acting in the interests of Māoridom. For example, the aforementioned Gerry Brownlee (National), prone to telling Māori MPs how best to behave as Māori legislators, criticizes Pakura Horomia, the Minister of Māori Affairs, for being too loyal to Labour, saying "he is a Minister of Māori Affairs who is much more interested in using his ministry to promote the best interests of the Labour Party than he is in Māori interests" (New Zealand, Parliamentary Debates, February 15, 2005, Gerry Brownlee MP). Other MPs constantly tell Māori MPs both that there is a conflict be- tween their party's interests and Māori interests, and that as good Māori representatives, they should put Māori interests first. One might anticipate that this tendency would have changed after the last election, when the newly formed Māori Party won four seats. In some sense, the Māori Party was established to circumvent this possible divide between loyalties. The best interests of the Māori Party are meant to be the best interests of Māoridom as a whole. Yet members of other parties still engage in this peculiar form of consociate education, telling members of the Māori Party how they should vote if they want to vote for Māori interests. In short, being a Māori legislator is understood as a category that one can fail to perform properly because of multiple loyalties. It is an identity category that inspires advice and corrections like no other.

\section{CONCLUSION}

The New Zealand parliamentary debates between 2003 and 2006 provide a useful case study for exploring the consequences of neoliberal perspectives for indigenous people. One sees how neoliberal policies are transformed into locally specific policies by turning to the ways in which, during this period, the New Zealand political parties characterized the indigenous Māori as either cultural or racial but not both. Māori members of parliament, in turn, must invent new strategies for representing their indigenous constituents' interests. This is a productive comparative example as indigenous people globally seek to navigate the possibilities and limitations enabled by the ways that neoliberal regimes everywhere are redefining what it means to be a culture bearer (Comaroff and Comaroff 2007).

Parliaments are, in part, arenas for contesting definitions. Legislators determine how to carve up the world through laws that result from debate and political compromise. What is intriguing about legislatures as arenas of law is that explicitness has its own peculiar hazards in these contexts. When a political party frames the need to redress a social inequity, the grounds for how best to understand this social inequity are immediately opened for debate. In discussing Māori as a legislative object, historical injustice competes with racial privilege as potential frames for understanding the context. Precisely because legislative structures promote contestation, when legislators introduce definitions of difference, the definition itself frequently becomes a topic of debate. Once the law has passed, this instability recedes into the background. But until the law becomes stabilized as a text, people's fundamental assumptions continually risk being challenged and changed. In New Zealand/Aotearoa, being explicit about culture has affected how parliamentarians address the culture bearers in their midst.

In the New Zealand parliament, being explicit about culture has gone hand in hand with attempts to contain culture. Both political parties try to use neoliberal logics to limit culture's epistemological challenges, with 
parliament's agonistic structure encouraging this effort to become a political divide. Their debates centers not around what culture is but whether culture as a skill set should be a legislative object. Yet this is not a skill set that everyone seems to possess equally. In making culture into a skill set, these politicians are defining some people as cultural but not others. Because of how the New Zealand parliament is organized, there are members of parliament, indigenous representatives, willing to disrupt others' strategic use of culture as containment. Māori MPs will use their personal experiences as culture bearers to speak against this containment, even criticizing the New Zealand parliament itself as a cultural arena. Pita Sharples, the coleader of the Māori Party, explained: "These sittings have been somewhat of a culture shock for three-quarters of the Māori Party, but we are adjusting OK" (New Zealand, Parliamentary Debates, December 15, 2005). With such statements, Maori MPs skillfully put culture to the work of dismantling the confines that their parliamentary colleagues try to build around culture itself.

ILANA Gershon Department of Communication and Culture, Indiana University, Bloomington, IN 47405

\section{NOTES}

Acknowledgments. I want to thank Keith Barber, Amy Cohen, Melissa Demian, Peter Fitzpatrick, Jane Goodman, Michael Goldsmith, Laura Graham, Shane Greene, Janelle Taylor, Matt Tomlinson, and three anonymous $A A$ reviewers for their invaluable comments and help with this article.

1. The historical scope of this article is limited to the period during which Don Brash led New Zealand's National Party.

2. The differences between the Māori and English versions of the Treaty make it difficult to determine what Māori chiefs thought they were signing in 1840.

3. Political scientists have been the most active in analyzing how the politics of recognition is enacted in legislatures. They tend to ask whether women have different leadership styles than men (Thomas 1994), whether ethnic minorities are best served by representatives of their own ethnicity (Coleman 1993), and whether women or ethnic minorities benefit by having guaranteed proportional representation (Htun 2004).

4. For an exception, see Bocarejo 2008.

5. This was not always the case. In 1975, when Ben Couch became the only Māori National MP, the other Māori MPs (all from Labour) often criticized him for not being sufficiently Māori.

6. Members of the Māori Party often begin their speeches with a few sentences in Māori.

7. At present, most Māori's first language is English. The Māori language is promoted in New Zealand through the educational system as well as government supported Māori television and radio stations.

8. Pita Sharples's (Māori Party) maiden speech is a striking exception.

9. This emphasis on precontact culture is an institutionally structured view of indigeneity that emerges in the New Zealand parliament only when legislators discuss Māori as a judicial object. In the following rare example, Michael Cullen (Labour) describes how the courts will choose to apply a law under discussion:

The test is a high one. ... Applicant groups must be able to demonstrate that the use or activity is integral to their culture and has been practiced substantially uninterrupted since 1840. [New Zealand, Parliamentary Debates, July 27, 2004, Michael Cullen MP]
10. Māori members of parliaments are not the only ones insisting that culture should not be static. Judy Turner, deputy leader of United Future, claimed that "all cultures are dynamic and responsive to phenomena, and often adjust over time" (New Zealand, Parliamentary Debates, May 3, 2006, Judy Turner MP).

11. For an analysis of corporate culture linked to ideas of diversity, see Gordon 1995.

12. Most Māori mps are notable exceptions: they do not speak in terms of "culture of." Only New Zealand First Māori MPs will, in line with their party's stance that Māori should be held responsible for their own successes and failures regardless of the structural inequalities encountered.

13. It is beyond the scope of this article to lay out the historical relationship between the National Party and its political allies contributing to this stance on race. For an elegant analysis, see Barber 2008.

14. In 2003-04, the terms race-based laws, race-based policies, racebased legislation, and similar turns of phrase were used approximately 286 times in parliamentary debates to describe the National Party's perspective.

15. Technically the acronym stands for Association of Consumers and Taxpayers, but no one would recognize this version. It is known as the ACT New Zealand party and it doesn't even mention the spelled-out version of its acronym on its website.

16. Although this speech did not take place in parliament, its points were reiterated there by Brash and other National MPs for months afterward. Readers familiar with New Zealand politics might want to claim Don Brash's speech initiated changes in how the National Party characterizes Māori. However, MPs actively distinguished between Māori as a culture or a race for over a year before Brash's speech.

17. A characteristic of New Zealand neoliberalism that makes it distinctly "first world" is that neoliberalism is not discussed as an economic policy imposed from the outside.

18. Because Māori are cognatic, Brash's argument also disregards Māori principles of kinship.

19. Thanks to Janelle Taylor for this point.

20. See Gershon 2001 for a critique of this political stance.

21 . Several members of parliament currently have degrees in anthropology, ranging from a BA to a Ph.D.

22. "Two-world view" refers to the existence of two distinct and equally valid perspectives: a Māori perspective and a Crown perspective.

23. This take on culture also encourages governments to require cultural mediators. See Gershon 2006 for a critique of government reliance on cultural mediators.

24. Being racial, and thus acultural, as the National Party advocated, was simply not a viable option for Māori MPs. When Brash began espousing this political argument, Māori politicians in his party, such as Georgina te Heuheu, made it clear they could not support National's new stance.

25. My thanks to Hervé Varenne for this methodological impulse.

\section{REFERENCES CITED}

Abu-Lughod, Lila

1991 Writing against Culture. In Recapturing Anthropology: Working in the Present. Richard Fox, ed. Pp. 137-162. Santa Fe: School of American Research Press.

Barber, Keith

2008 Indigenous Rights or "Racial Privileges": The Rhetoric of Race in New Zealand Politics. The Asia Pacific Journal of Anthropology 9(2):141-156.

Bocarejo, Diana

2008 Reconfiguring the Political Landscape after the Multicultural Turn: Law, Politics, and the Spatialization of Difference in Colombia. Ph.D. dissertation, Department of Anthropology, University of Chicago.

Briggs, Charles L.

2001 Modernity, Cultural Reasoning, and the Institutionalization of Social Inequality: Racializing Death in a Venezuelan Cholera Epidemic. Comparative Studies in Society and History 43(4):665-700. 
Chock, Phyllis Pease

1991 "Illegal Aliens" and "Opportunity": Myth-Making in Congressional Testimony. American Ethnologist 18:279-294.

1996 No New Women: Gender, "Alien," and "Citizen" in the Congressional Debate on Immigration. PoLAR: Political and Legal Anthropology Review 19:1-10.

Coleman, Mary DeLorse

1993 Legislators, Law, and Public Policy: Political Change in Mississippi and the South. Westport, CT: Greenwood Press.

Comaroff, Jean, and John Comaroff

2007 Ethnicity, Inc. Presidential Address at the American Ethnological Society Meeting, Toronto, Canada, May 9-12.

Conklin, Beth

1997 Body Paint, Feathers, and VCRs: Aesthetics and Authenticity in Amazonian Activism. American Ethnologist 24(4):711737.

Conklin, Beth, and Laura Graham

1995 The Shifting Middle Ground: Amazonian Indians and EcoPolitics. American Anthropologist 97(4):695-710.

Coombe, Rosemary

2005 Legal Claims to Culture in and against the Market: Neoliberalism and the Global Proliferation of Meaningful Difference. Law, Culture and the Humanities 1:35-52.

Dusenbery, Verne

1997 The Poetics and Politics of Recognition: Diasporan Sikhs in Pluralist Polities. American Ethnologist 24(4):738-762.

Fleras, Augie, and Paul Spoonley

1999 Recalling Aotearoa: Indigenous Politics and Ethnic Relations in New Zealand. Auckland: Oxford University Press.

Gershon, Ilana

2001 Going Nuclear: New Zealand Bureacratic Fantasies of Samoan Extended Families. In New Directions in Anthropological Kinship. Linda Stone, ed. Pp. 303-321. Lanham, MD: Rowman and Littlefield.

2006 When Culture Is Not A System: Why Samoan Cultural Brokers Can Not Do Their Job. Ethnos 71(4):533-558.

Goldsmith, Michael

2003 Culture, For and Against: Patterns of "Culturespeak" in New Zealand. Journal of Polynesian Society 112(3):280-294.

Gordon, Avery

1995 The Work of Corporate Culture: Diversity Management. Social Text 44:3-30.

Graham, Laura

2002 How Should an Indian Speak? Brazilian Indians and the Symbolic Politics of Language Choice in the International Public Sphere. In Indigenous Movements, Self-Representation, and the State in Latin America. Kay Warren and Jean Jackson, eds. Pp. 181-228. Austin: University of Texas Press.

Hale, Charles

2006 Mas Que Un Indio: Racial Ambivalence and Neoliberal Multiculturalism in Guatemala. Santa Fe: School of American Research Press.

Handler, Richard

1988 Nationalism and the Politics of Culture in Quebec. Madison: University of Wisconsin Press.

Htun, Mala

2004 Is Gender Like Ethnicity? The Political Representation of Identity Groups. Perspectives on Politics 2(3):439-458.

Jackson, Jean

1991 Being and Becoming an Indian in the Vaupés. In NationState and Indian in Latin America. Greg Urban and Joel Sherzer, eds. Pp. 131-155. Austin: University of Texas Press.

1995 Culture, Genuine and Spurious: The Politics of Indianness in the Vaupés, Colombia. American Ethnologist 22(1):3-27.

Murray, David

2000 Haka Fracas? The Dialectics of Identity in Discussions of a Contemporary Māori Dance. Australian Journal of Anthropology 11(3):14-26.
Oakdale, Suzanne

2004 The Culture-Conscious Brazilian Indian: Representing and Reworking Indianness in Kayabi Political Discourse. American Ethnologist 31(1):60-75.

Povinelli, Elizabeth

2002 The Cunning of Recognition: Indigneous Alterities and the Making of Australian Multiculturalism. Durham, NC: Duke University Press.

Ramos, Alcida Rita

1998 Indigenism: Ethnic Politics in Brazil. Madison: University of Wisconsin Press.

Santiago-Irizarry, Vilma

1996 Culture as Cure. Cultural Anthropology 11(1):3-24.

Segal, Daniel

1998 The Hypervisible and the Masked: Some Thoughts on the Mutual Embeddedness of "Race" and "Class" in the United States Now. In Democracy and Ethnography: Constructing Identities in Multicultural Liberal States. Carol Greenhouse, ed. Pp. 50-60. New York: State University of New York Press.

Silverstein, Michael

1998 The Uses and Utility of Ideology. A Commentary. In Language Ideologies: Practice and Theory. B. Schieffelin, K. Woolard, and P. Kroskrity, eds. Pp. 123-145. New York: Oxford University Press.

2003 Indexical Order and the Dialectics of Sociolinguistic Life. Language and Communication 23(3-4):193-229.

Sissons, Jeffrey

1993 The Systematisation of Tradition: Maori Culture as a Strategic Resource. Oceania 64(2):97-117.

Strathern, Marilyn

1995 The Nice Thing about Culture Is That Everyone Has It. In Shifting Contexts: Transformations in Anthropological Knowledge. Marilyn Strathern, ed. Pp. 153-176. London: Routledge.

Taylor, Janelle

2003 Confronting "Culture" in Medicine's "Culture of No Culture." Academic Medicine 78(6):555-559.

Thomas, Sue

1994 How Women Legislate. Oxford: Oxford University Press.

Urciuoli, Bonnie

1996 Exposing Prejudice: Puerto Rican Experiences of Language, Race, and Class. Boulder, CO: Westview.

In press Educating the Community: The "Cultural" Work of Undergraduate Multicultural Organizations. Journal of Linguistic Anthropology.

Wade, Peter

1993 “Race," Nature and Culture. Man 28(1):17-34.

Wagner, Roy

1981 The Invention of Culture. Chicago: University of Chicago Press.

Wanna, John

2005 New Zealand's Westminster Trajectory. In Westminster Legacies: Democracy and Responsible Government in Asia and the Pacific. Haig Patapan, John Wanna, and Patrick Weller, eds. Pp. 153-185. Sydney: University of New South Wales Press.

Warren, Kay, and Jean Jackson, ed.

2002 Indigenous Movements, Self-Representation, and the State in Latin America. Austin: University of Texas Press.

Webster, Steven

1998 Patrons of Māori Culture: Power, Theory, and Ideology in the Māori Renaissance. Dunedin: University of Otago Press.

Wetherell, Margaret, and Jonathan Potter

1992 Mapping the Language of Racism: Discourse and the Legitimation of Exploitation. New York: Columbia University Press. 